\title{
POLITICAL REALITY AND CULTURAL SUPERIORITY: SONG CHINA'S ATTITUDE TOWARD THE KHITAN LIAO*
}

\author{
HANG LIN \\ Department of History, Hangzhou Normal University \\ 2318 Yuhangtang Rd. Hangzhou 311121, China \\ e-mail: hang.lin@hznu.edu.cn
}

In the 10th century, the nomadic Khitan, with their Liao dynasty, became the most dominant power in East Asia, posing enormous threats to the Chinese Song dynasty in the south. Based on an analysis of the traditional Chinese world view, this paper examines the two opposing views of the Song Chinese about their Khitan neighbours in the north. The Song Chinese acknowledged the military prowess of the Khitan and thus advocated flexible diplomatic policies based on realistic observation and careful assessment, demonstrated by the diplomatic parity set by the Treaty of Chanyuan in 1005. In the meantime, many held firm belief in their cultural superiority over the "barbarians", which derived from the tradition of a cultural sino-centrism. The Song looked for Confucian sources to justify their concession by turning their attention to the cultivation of virtue and were confident that they were the centre of culture and civilisation.

Key words: diplomatic relations, cultural superiority, Khitan, Liao dynasty, Song dynasty.

Servants and slaves insult their masters, Barbarians invade China.

This injustice has been so since ancient age,

To resolve the problem there is no way. ${ }^{1}$

Shao Yong 邵雍 (1011-1077)

Throughout China's long history, the presence of foreign menace has always loomed large. Indeed, the record of China's conflicts with her pastoral nomadic and semi-

* Acknowledgement: The research of this paper is funded by the Hangzhou Young Talents in Social Sciences Program (2018RCZX11) and the Qinshen Research Project of Hangzhou Normal University.

${ }^{1}$ Translated from the poem "Moaning on Calamities" (Sihuan yin 思患吟) collected in Shao's anthology Yichuan jirang ji 伊川擊壤集 (compiled around 1080, reprint 1922, 16: 117). For a biography of Shao, see Franke (1976, pp. 849-857). 
nomadic neighbours in Central and Northeastern Asia is a long and convoluted one. Limited by the peculiar environment of the steppe and grassland, peoples and tribes to the north raided Chinese territory to obtain grain, textile, and crafted goods. Later on, they also developed a taste for Chinese tea, porcelain, and other commodities. When these items could not be acquired peacefully through trade, they attacked Chinese settlements to obtain them by force.

In response to such raids, a few Chinese dynasties - such as the Han 漢 (206 BC-220 AD) and Tang 唐 (618-907) - sought to and sometimes did vanquish the adjacent nomadic peoples. These campaigns became a part of the standard "pacification" narrative for China's relations with its "barbarian" neighbours. Yet, during periods of internal disunity, when non-Chinese regimes took partial control of Chinese territory and no Chinese court could truthfully claim to be the sole existing authority, a different historical reality emerges. The prolonged era of north-south division that lasted from the end of the Han dynasty to reunification of Sui 隋 (589-618) saw the first example of this reality with a succession of non-Chinese regimes that devastated north China. The most notable case of diplomatic parity, at least in political and military terms, was the one between the nomadic Northern Wei 北魏 (386-534) of the Xianbei 鲜卑 people and its Chinese counterparts in the south (Di Cosmo 2002; Lewis 2009). Despite frequent wars that disrupted and impacted the conduct of foreign affairs, these states always attempted to carefully nurture and maintain mutual relations on an equal footing. ${ }^{2}$ This development marked a milestone in China's history of interacting with non-Chinese states in a manner of recognising each other as equals; furthermore, it established to some extent a set of diplomatic practices that was continued by the later empires, in particular the Song 宋 (960-1279) and the Liao 遼 $(907-1125)^{3}$

Fifty years after the collapse of the once-mighty Tang empire, its Chinese territory were spilt into the Ten Kingdoms 十國, whose rulers were generally Chinese, and the Five Dynasties 五代, whose potentates were mostly of foreign or half-foreign origin. ${ }^{4}$ When the Song dynasty ended the Five Dynasties in 960 , it had to accept a geopolitical landscape in which the Chinese were surrounded by militant neighbours: in the southwest the Nanzhao 南詔 and Annan 安南 had established themselves as regional powers before the founding of the Song; along the western border were the Tibetans and the Tangut kingdom of Xi Xia 西夏 (1038-1227); and further north, a new and powerful nomadic group from southern Mongolia known as the Khitan (Qidan 契丹) had consolidated the Mongolian steppe and Manchuria, absorbed a large

${ }^{2}$ Various historical records on diplomatic exchanges between these states show that both sides of the Chinese and the Toba carefully selected eloquent and knowledgeable envoys from the gentry class to ensure their diplomatic equality. On the relations between the Northern Wei and its southern neighbours, see Eberhard (1949, pp. 162-167).

${ }^{3}$ Divided by the fall of the Song capital into the hands of the Jurchen in 1127 and the subsequent reduction of territory to the south of the Huai river, the Song period is commonly divided into the Northern Song 北宋 (960-1127) and the Southern Song 南宋 (1127-1276).

${ }^{4}$ Although somehow dated, the standard source on this period is Wang (1963). For a recent account, see Lorge (2011). 
tract of land inside China stretching from present Beijing to modern Datong (Shanxi province), and founded a Chinese-style dynasty named the Liao. The Song was one of the most important political and military players during this era, but it was not the principal one. The Song court, then, found that they could not impose a Chinese-centric scheme of conducting foreign relations on their Khitan neighbours (Kuhn 2009, p. 20).

Both John King Fairbank $(1941,1968)$ and Mark Mancall $(1963,1968)$ made ground-breaking contributions to the scholarship on imperial China's view of world order and foreign relations. Their studies laid the foundation for our current understanding of how the Chinese perceived their neighbouring peoples and the outside world. Yet, there have been few attempts to place these inquiries in the particular setting of Song-Liao parity. How did the Song Chinese perceive and view their relations to the Khitan? Were such perceptions and views unified within the Song? If not, what were the differences? In what way did the different views of Khitan influence Song policy towards their pastoral neighbours in the north and vice versa? What can these views inform us about China's historical conception of world order and foreign relations?

In an effort to answer these questions, this paper analyses the Song scholars' and officials' diverse views toward the Khitan. Its first part will outline the origin and characteristics of the traditional Chinese world order and its conceptualisation of foreign relations, focusing in particular on the stereotypes of non-Chinese peoples on Chinese borders, known as "barbarians" to the Chinese. Then, drawing on earlier observations by Morris Rossabi (1983), Jing-shen Tao [Jingsheng Tao] (1988) and David Curtis Wright (2005), it analyses two opposing views on the Khitan within the Song through an investigation of contemporary Song writings, both official and private. This examination reveals that Song officials understood the impracticality of challenging the status quo and thus advocated relatively realistic and flexible policies towards the Liao. At the same time, however, they also chose to emphasise Song's cultural superiority over the Khitan - even though the Song could not claim to be the political or military centre of the world, they were confident that they were the centre of culture and civilisation.

\section{Civilised and Barbarian: Traditional Chinese World Order}

As early as the first millennium BC, there already existed enclaves of non-Han tribes on the northern and western frontiers of China. Indeed, their incursions into Chinese territory eventually wiped out the Western Zhou 西周 dynasty (1122 BC-771 BC) and forced the Chinese court to move eastward. It was probably during this time that China's traditional, specifically Confucian, attitudes toward alien peoples began to take shape. A famous passage from the Book of Poetry (Shijing 詩經) quoted in the Works of Mencius reads: 
"Under the whole heaven, every spot is the sovereign's ground; To the borders of the land, every individual is the sovereign's minister" (Legge 1861, p. 352). ${ }^{5}$

These words shine lights on imperial China's somewhat amorphous idea of the proper world order. Encompassing the known and unknown territories, the world in Chinese eyes became "all under heaven" (tianxia 天下), of which China perceived itself to be the very centre (Fairbank 1968, p. 2). In this vague but pervasive sense of an all-embracing domain of tianxia, the Chinese emperor claimed to be the Son of Heaven (tianzi 天子), the one who had supreme power to reign and rule over all human affairs. China's very name, Zhongguo 中國, denoted a sense of the "Middle Kingdom" or "Central State". Traditional Chinese perception of its place in the world was thus characterised by an overwhelming sense of "sino-centrism" that centred on Chinese attitudes toward itself and others for over two millennia, from the 3rd century BC to the early 20th century (Wang 1999, p. 287).

The concept of Zhongguo, however, was not a fixed territory limited by geographical boundaries. Instead of conceptualising it by definition of territory or sovereignty, the real Chinese understanding of the world is probably best understood through a cultural approach. The ancient Chinese asserted that they possessed a sophisticated culture, a written language, as well as magnificent cities and palaces, all of which their neighbours sorely lacked. Thus the Chinese divided the universe into two worlds: “inside were the Chinese (zhuxia 諸夏) and outside were the barbarians (yidi 夷敵)" (Chunqiu Gongyang zhuan, 371). ${ }^{6}$ In other words, the civilised Chinese centre was surrounded by an uncivilised world of barbarians. They could be allowed to reside in the Chinese world and be recognised as equals of Chinese, provided that they adopted Chinese customs and were assimilated to Chinese cultural norms.

Against this conceptual background, one may detect a general tone of arrogance and even cultural chauvinism from the ancient Chinese orthodox classics. In the Chinese view, what constituted China was not, at least not solely, fixed border lines which defined its territory and political sovereignty, but rather a self-consciousness which was primarily based on the moral commitment created from civil achievement as well as the culturally hierarchical and self-centred attitude towards the peripheral peoples (Smith 1996, p. 7). In other words, China's version of culturalism did not concern itself with geographical separation, but placed a premium on the distinction between civilisation and barbarity. The state of barbarity, in traditional Chinese conception, was not designated by race, religion, language, or national origin. Instead, civilisation and barbarity were conceptually related in that "they defined each other" (Mancall 1968, p. 63). "Barbarians" were those who "did not accept Chinese civilisation and who knew not the refinement of ceremony, music, and culture"

${ }^{5}$ Legge's term "minister" for chen 臣, as far as I am concerned, is an over-translation, while "servant" or "subject" might be a more accurate one.

${ }^{6} \mathrm{Xia}$ 夏 is traditionally considered as the region of the Xia dynasty (c. 2070-c. $1600 \mathrm{BC}$ ), the first dynasty in traditional Chinese history. It also denotes the people of the Xia, who constituted the first group of the Chinese nation. On the origin and meaning of xia, see Feng (2016, pp. $32-35)$. 
(Hsu 1960, pp. 6-7). Peoples living outside the Chinese realm and refusing to submit themselves to civilisation (that is, Chinese civilisation) were not foreign peoples, but uncultivated, outlandish peoples culturally inferior to the Chinese.

This cultural ethnocentrism is clearly seen in the terms used to denigrate all non-Chinese people outside the Chinese civilisation. As described in the Confucian classic the Book of Rites (Liji 禮記), "the wild tribes are the $y i$ 夷 in the east, the $d i$ 狄 in the north, the rong 戎 in the west, and the man 蠻 in the south. However great their territories are, they are called minors" (Legge 1885, p. 111). ${ }^{7}$ In fact, nothing expresses the contemptuous sentiments so well as the ideographic characters themselves. The term for southern barbarians, man, is written with an "insect" (chong 蟲) radical, and that for the northern barbarians, $d i$, is written with a "dog" (quan 犬) radical. In Chinese eyes, barbarians were considered no different from the lower animals since they were ignorant of the beauty of the Chinese way of life and lacked the sophistication to appreciate reason and ethics as the Chinese did. By the same token, "the Chinese became barbarians if they debased themselves through uncivil practices" (Hsu 1960, pp. 6-8). This perception of cultural superiority over their neighbours is echoed in Mencius's argument that "I have heard of men using the doctrines of our great land to change barbarians, but I have never yet heard of any being changed by barbarians" (Legge 1861, pp. 253-254).

What, then, was the proper and ideal way to deal with these "uncivilised barbarians"? Constant raids by the foreign tribes made Confucius (551 BC-479 BC) deeply concerned about the preservation of Chinese culture that it should not be corrupted by barbarian customs, as he stated in the Chronicles of Zuo (Zuozhuan 左傳): "those distant people have nothing to do with our great land; those wild tribes must not be permitted to create disorder among our flowery states" (Legge 1872, p. 777). In the same book, Confucius further commented: "It is virtue (de 德) by which the people of the Middle State are cherished; It is by severity which the wild tribes around are awed" (Legge 1872, p. 196). Confucius's idea, more positively interpreted, was to introduce the high culture of Chinese civilisation and moral values to the "barbarian" peoples and thereby assimilate them into Chinese society. The corollary of this theory was that the way to assimilate barbarians, as prescribed by the classical teachings, was to win their admiration for the grandeur of Chinese civilisation through correct conduct according to certain virtuous norms (Wang 1999, p. 288). In other words, the Chinese did not need to actively convert others to their way of life, ideas, values, and political system. The barbarians, on the other hand, were expected to voluntarily seek out Chinese civilisation and be transformed in order to enjoy its benefits.

But what if the barbarians, especially those militarily and politically strong enough to rival their Chinese counterparts, were not sufficiently bedazzled by China's civilisation and were not willing to submit themselves to the Chinese cultural realm? In such cases, the Chinese would have to let go of - or at least conceal - their sense

\footnotetext{
${ }^{7}$ Whereas Legge translated $z i$ 子 as "counts", given the context of the sentence, "minors" should be more appropriate.
} 
of cultural superiority and find different means of handling these potentially powerful and dangerous adversaries, as shown in the way the Northern Song Chinese viewed and dealt with the Khitan, their rival paramount in the north.

\section{From Diplomatic Initiation to the Treaty of Chanyuan: An Official Attitude of Parity}

As the once-dominant Tang empire finally crumbled in 907, the Khitan, distant descendants of the Xianbei, seized this historical opportunity to rise from the Xar Moron 西拉木伦 Valley and established a dynasty in north China. ${ }^{8}$ The Khitan soon controlled a broad swath of steppe and grasslands in north Asia, with Yelü Abaoji 耶律阿保機 (b. 872, reigned as Emperor Taizu 916-926) assuming the title of emperor in a formal ceremony in Chinese fashion in 916. In 938, during the reign of Abaoji's son Yelü Denguang 耶律德光 (b. 902, reigned as Emperor Taizong 927942), the Khitan acquired the sixteen prefectures of Yan and Yun (Yan-Yun shiliu zhou 燕雲十六州), a vast region stretching from present-day Beijing to modern Datong (Shanxi province). This marked the beginning of a hybrid multi-ethnic empire (Twitchett-Tietze 1994, p. 70). ${ }^{9}$ In 947, the Khitan ended Later Jin 後晋 (936-947) and finally gave their budding empire the name of Liao 遼, the Chinese name of the most important watercourse (the Xar Moron) in their homeland. While their Chinese counterparts were competing for survival and dominance, the Khitan successfully established themselves as the dominant power in the early 10th century.

In 960, the Song dynasty vanquished the last of the Five Dynasties, the Later Zhou 後周 (951-960). At the time, it looked as though it would be just another one of the short-lived dynasties of north China. The first two Song emperors, Taizu (r. 960-976) and Taizong (r. 976-997), spared no effort in wiping out regional regimes, in particular those in the south and the west, to consolidate their empire. After the Song annexed the Northern Han 北漢 (951-979), a subordinate state of the Khitan, it finally had to directly confront its eminent rival in the north. Encouraged by his previous victory, Song Taizong embarked on his first campaign against the Liao in the same year, only to suffer a major defeat. ${ }^{10}$

It should be noted, however, that the first contacts between the Song and the Liao had already been initiated before this military confrontation. When the Song and the Liao courts made indirect contacts in 974 in the hopes of establishing peaceful

${ }^{8}$ The chronology of the Khitan before 930 is somehow contradictory. On their early history, see Wittfogel - Feng (1949). See also Twitchett-Tietze (1994, pp. 43-57) and Marsone (2011) for the predynastic and early dynastic history of the Liao.

${ }^{9}$ The founding ruler of the Later Jin, Shi Jingtang (r. 936-942), offered the sixteen prefectures to the Khitan in exchange for their military support. For the Khitan cession of the region, see also Mote (1999, pp. 63-65).

${ }^{10}$ The Song troops were defeated by the Khitan force at Liao's southern capital Yanjing, today's Beijing, and Song Taizong barely escaped with his life. On the campaign, see Liaoshi, 12: 109. 
relations, both sides were relatively careful. In his letter to the Song, Yelü Cong 耶律 琮 (927-980), the Khitan prefect of Zhuozhou 溷州, wrote:

"There has never been the slightest fissure between our two courts. If envoys were exchanged and the intentions of our rulers were bared, this would rest our weary people and restore our good relations. ... Why should we not have generations of friendly alliance and a regular exchange of gifts?" (Song huiyao jigao [hereafter as SHYJG], 8: 7673)

To this conciliatory note, his Song counterparts in Xiongzhou 雄州, Sun Quanxing 孫全興 (d. 981), was authorised to compose a favourable reply, proposing that the two states should become "eternal allies" (yuguo 與國) (Songshi, 3: 43). This correspondence served as a diplomatic overture to normalise the relations between the two. The following four years witnessed a regular exchange of envoys: in 975, the Liao dispatched several missions; when Song Taizu died in 976, a special Liao envoy brought condolences, followed by another on the occasion of Taizong's succession; envoys from the Liao arrived again in 977 and 978, and they were all feted and presented with rich gifts. Each time the Song also sent missions to Liao to express gratitude (SHYJG, 8: 7673; Songshi, 3: 43-46; Liaoshi, 9: 94-101). During this period, the Song-Liao bilateral relationship was aimed at preserving the status quo and based primarily on the exchange of embassies and gifts.

Song Taizong's 979 campaign brought an end to the hitherto peaceful relations. The following two decades were marked by continued hostilities along the SongLiao border, peaking with Taizong's second failed expedition against the Liao in 986 until the Khitan launched a full-scale war against the Song in $1004 .{ }^{11}$ Given the military strength of the Liao, the war ended predictably with several Song defeats. At Chanzhou 澶州 on the Yellow River, a "treaty of alliance" was signed in 1005, known as the Treaty of Chanyuan 澶淵 (Songshi, 7: 125-127; Liaoshi, 14: 160). The main content of the treaty consisted of the following:

1. Establishment of a friendly relationship between the Song and the Liao;

2. Annual payments of 100,000 teals (ca. $3730 \mathrm{~kg}$ ) of silver and 200,000 bolts (ca. $2400 \mathrm{~km}$ ) of silk to the Liao by the Song as "military compensation";

3. Demarcation of borders between the two states;

4. An agreement that neither side should construct new fortifications and canals along the border;

5. An agreement that neither side should detain robbers and fugitives;

6. A pledge of solemn oath with a religious sanction in case of contravention. ${ }^{12}$

What emerges from the treaty is a strong sense of diplomatic parity, which in Wang Gungwu's (1983, p. 55) words was "the nearest thing to equality in Chinese history until modern times". Such diplomatic parity is further revealed in practices not stipu-

${ }^{11}$ On the 986 defeat, see Twitchett-Tietze (1994, pp. 85-87); Tao (1988, pp. 10-14).

12 The text of the treaty is recorded in Xu Zizhi tongjian changbian, 58: 22b-23a. On details of the treaty, see Schwarz-Schilling (1959, pp. 40-50, 108-137) and Wright (2005). 
lated in the clause texts, since a fictitious kinship, which extended to members of the imperial households, was established between the two courts. The Song emperor Zhenzong (b. 968, r. 997-1022) became the "elder brother" of the Liao emperor Shengzong (b. 972, r. 983-1031), and this pattern was applied to the subsequent generations of emperors. ${ }^{13}$ In the same manner, the two states were established as "brotherly states” (xiongdi zhi guo 兄弟之國) (Twitchett-Tietze 1994, pp. 104-110; Wright 2005, pp. 145-152). Missions were regularly sent to celebrate New Year's Day and the birthdays of the emperors (and that of the Liao empress dowagers). ${ }^{14}$ Upon receiving the news of the death of an emperor, the other would immediately dispatch envoys to offer his condolences and for seven days no audiences to officials would be given. A detailed system of protocol was observed for receiving the envoys, including rules regarding meal dishes, seating arrangements, location of accommodation, as well as manner of kneeling and prostration (Schwarz-Schilling 1959, pp. 56-57; Kuhn 2009, p. 45).

Aside from these exchanges, a new diplomatic language was also developed. After the Treaty of Chanyuan was signed, the Song court immediately issued an edict to change all place names hitherto containing characters such as "caitiff" ( $l u$ 虜) and "western barbarian" (rong 戎) in order to avoid potentially insulting the Khitan. The prefectures Weilu 威虜 (literally “deterring the caitiff”, in today's Shangrao county in Jiangxi) was changed to Guangxin 廣信 (literally “extending faith”), and Jingrong 靖 戎 (literally "pacifying the western barbarian", in today's Xushui county in Hebei) to Ansu 安肅 (literally "peaceful and solemn"). In addition, taboos concerning the Liao imperial family were observed. For instance, when Han Yi 韓億 $(972-1044)$ was sent in 1026 to celebrate the birthday of Liao's empress dowager, his name was "temporarily changed" to the homophone Yi 意 in reference to Liao Taizu's Chinese name Yi 億 (Xu Zizhi tongjian changbian [hereafter as XZZTJCB], 104: 927). ${ }^{15}$ Four years later, another Song envoy Zhang Yi 張億 (fl. 1030s) also had his name changed to another homophone Yi 易 by imperial order when he accepted the mission (Liaoshi, 17: 205). To handle the exchange of state letters with the Khitan, the Song established a special office, the State Letters Bureau (Guoxin 國信司), to guard against committing literary faux-pas in their diplomatic correspondences $(X Z Z T J C B, 64: 12 \mathrm{~b}){ }^{16}$

In the letter to the Liao during the negotiation of the Treaty of Chanyuan, the Song indicated that the two states (erguo 二國) should be friendly neighbours (Song $d a$ zhaoling ji, 288: 882). After the treaty had been concluded, the writers of diplomatic letters often addressed each other as the "northern dynasty" (beichao 北朝) and the "southern dynasty" (nanchao 南朝) (Hansen 2000, p. 307). Numerous reports and memorials from local governments on the Song-Liao border termed the Khitan as "northerners" (beiren 北人) instead of pejoratives such as "caitiff" $(l u)$ or "barbar-

${ }^{13}$ For the imaged relations between Song and Liao emperors, see Tao (1985, pp. 26-27).

${ }^{14}$ See Song da zhaoling ji, Chapters 288-232 for varieties of examples.

${ }^{15}$ The Liao source renders his name as Han Yi 韓翼, see Liaoshi, 17: 200. For a biography of Han, see Franke (1976, pp. 370-373). On the Song practice to avoid the naming taboo of members of the Liao imperial household, see Wang Cengyu (2005).

${ }^{16}$ In 1054, the bureau was renamed as Office of State Letters (guoxin suo 國信所). 
ian”胡 $(h u)$, and their land as the “northern side” (beijie 北界) (Tao-Wang 1974, pp. 723-740). Throughout official texts of the Song, terms as "the Great Song" (Da Song 大宋), “the Great Liao” (Da Liao 大遼) or “the Great Khitan” (Da Qidan 大契 丹) appeared in state letters to the Liao, imperial edicts conveyed to Liao envoys, as well as replies acknowledging the receipt of gifts and expressing appreciation to the Liao court (Tao 1985, pp. 99-100). ${ }^{17}$

The neutral tone of the Song's diplomatic language concerning the Liao is vividly illustrated in Huarong Lu-Wei xinlu 華戎魯衛信錄 (Truthful Records between China and Barbarian in Lu and Wei), complied by Su Song 蘇頌 (1020-1101) who participated in diplomatic missions to the Liao in 1068 and $1077 .{ }^{18}$ Commissioned by the Song emperor Shenzong (r. 1067-1085) in 1081, the work included descriptions of Liao government and customs, Song correspondences with the Liao, and outlines of routes of the envoys. ${ }^{19}$ Although the main body of this work has been lost, its extant preface informs us that the chapters on Liao envoys, state letters, and documents appear under the headings of "northern envoys" (beishi 北使), “northern letters" (beixin 北信), and “northern correspondence" (beishu 北書). It is also stated in the preface that its chapters contain sections on "Liao imperial genealogy" (shixi 世系) and "Khitan national customs" (guosu 國俗), and the most common terms referring to the Khitan are the "northerners" (beiren 北人) (Su Weigong wenji, 66: 1a-5a). When the work was completed and presented to the throne in 1083, Shenzong was pleased and praised it "as proper as the text of the [section] 'Sequences of the Hexagrams' [of the Book of Changes]" and personally assigned the name of the work (Songshi, 340: 10865). But interestingly, the emperor used the term rong (barbarian) in the book's title, which somehow shows that the emperor may not be as neutral as the writer.

The Song official rendering of terms concerning the Khitan is also seen in Sima Guang's 司馬光 (1019-1086) Zizhi tongjian 資治通鑑 (Comprehensive Mirror for Aid in Government), one of the most important contemporary histories. This seminal work referred to the Song's northern neighbours simply as "Khitan" (Qidan), never inferior "barbarians" (Tao 1988, p. 77). In his four memorials to the emperor between 1065 and 1086, Sima Guang talked about the "caitiff" only once in his 1067 memorial, while in all other cases he used "Khitan" or "enemy" (di 敵) (Tao-Wang 1974, pp. 587-588, 600-601, 782-783, 784). This attitude resurfaced in Li Tao's 李壽 (1115-1184) Xu Zizhi tongjian changbian 續資治通鑑長編 (Collected Data for "A Continuation of the Comprehensive Mirror for Aid in Government"), which contained a wealth of terminological information regarding Song official documents and the veritable records (shilu 實錄). In almost all instances describing their northern neighbours, terms of "Khitan" (Qidan) and "northerners" (beiren) were used. Moreover,

${ }^{17}$ Examples of these texts can be found in Su Weigong wenji, Chapters 25-26; Nanyang ji, Chapter 15; Huayang ji, Chapters 18, 21, 23-25, 30-32; Fan taishi ji, Chapters 28-32.

${ }_{18}^{18}$ For a biography of Su, see Franke (1976, pp. 969-971).

${ }^{19}$ It took Su Song two years to finish the compilation. He was appointed "accompanying officer" (banshi 伴使) to receive and escort the Liao envoy during the compilation in 1082. On the work, see Jiang (2009). 
terms of "China" (Zhongguo 中國) and "Liao" or the "northern dynasty" (beichao) appeared frequently in tandem in referring to the Song and the Liao (Tao 1985, pp. 235-236). The usage of these neutral terms, instead of derogatory ones, reflects a clear sense of equality rather than disparagement.

\section{Realistic Assessment and Flexible Policy}

The fraternal treaty of 1005 brought a century of peace between the Song and the Liao. Although uneasy at times, in particular when the Liao-Xi Xia alliance of 1042 forced the signing of another treaty that increased Song's annual payment obligation to a total of 500,000 units of silver and silk (Qidan guozhi, 20: 5a; Tao 1988, pp. 5766 ), the brotherly relations sworn by the two emperors had been kept and no significant military confrontation occurred. ${ }^{20}$ The two treaties succeeded in reaching "a nonaggressive foreign policy with minimal concessions" (Kuhn 2009, p. 45), since the payments, even after increase, constituted less than two percent of Song annual military expenditure during wartime (XZZTJCB, 150: 16a; Hansen 2000, p. 307). For the Song, the cost of peace far outweighed the cost of war: it was far more economical to bring hostilities to an end at an affordable price than to wage war or to cede territory. Buying-off their nomadic neighbours, as they had done with the Treaty of Chanyuan, was reaffirmed as a successful model for the Song not only in 1042, but again with the peace treaties with the Tangut Xi Xia in 1044 and with the Jurchen Jin 金 (11151234) in 1141, 1164, and 1208.

However, behind such economic considerations, there was probably also an increasingly clear understanding of the might of the Khitan's cavalry forces. In fact, a number of Song officials were realistic enough to accurately assess the Khitan's military power well before the treaty of 1005. After Song Taizong's failed expedition against the Liao in 979, his advisors Li Fang 李昉 (925-996) and Hu Meng 扈蒙 (915-986) realised that the Song's military was no match for the Liao and entreated the emperor to focus on strengthening the troops and securing financial resources instead of planning new military actions (SHYJG, 8: 7676; XZZTJCB, 21: 11a-12a). ${ }^{21}$ Following the second Song defeat in 986, Zhao Pu 趙普 (922-992), Song Taizu's most trusted minister, remonstrated that no further military actions should be carried out, arguing that military ventures were detrimental to both the people and the state (Tao-Wang 1983, pp. 111-113).

Three years later, Taizong asked his officials to express their views on national defence and foreign policy. Almost all of them favoured peaceful approaches, the most common argument being that there was no guarantee that a war would be successful and war was the worst policy if it was an ill-prepared one (XZZTJCB, 150: 16a). The memorial of Zhang Ji 張洎 (933-997) was representative of his colleagues'

\footnotetext{
${ }^{20}$ For details of the backgrounds and negotiation of the treaty, see Tao (1985, p. 232); Kuhn (2009, p. 46).

${ }^{21}$ See Franke (1976, pp. 552-555) for a biography of Li.
} 
opinion. ${ }^{22}$ After weighing the pros and cons of various methods to deal with their enemies on the border, Zhang argued that the best choice was to adopt an active defensive policy to resist the enemies when they invaded. However, given the Song's limited military capacity vis-à-vis that of the Liao, Zhang concluded that even this policy was not in fact feasible. He then proposed that the only practical alternative left was:

"[...] to put away the armour and bows, use humble words, give generous gifts, send a princess to obtain friendship, and transport goods in order to establish firm bonds. Although this would diminish the emperor's dignity, it could, for a while, end warfare along the three borders" (SHYJG, 8: 7682-7683). ${ }^{23}$

To bolster his argument, Zhang cited the example of how Tang Taizong (r. 626-649) indulged the greed of the Turks for years until he was ready to send forces strong enough to destroy them. Zhang believed that the Khitan were of the same ilk and therefore advised the Song emperor to bow low in order to save Song from danger and to wait for the right moment. Most of Zhang's suggestions were incorporated into the Treaty of Chanyuan. The Song did not need to send a princess, but everything else was exactly what Zhang had proposed.

These realistic views must have an enormous impact on the emperor. Emperor Taizong was aware that he had not, and would probably not, defeat the Khitan to achieve a true unification of China, thus he refused to approve his officials' suggestion to confer an honorary title on himself, citing his failure to recover the sixteen prefectures as the reason (Song da zhaoling ji, 3: 11). During negotiations of the treaty in 1005, when the Song emperor Zhenzong received Liao's proposal for peace, he told his ministers that the periods of great prosperity in the past had been those when the sovereign of virtue profited from making peace with the "barbarian" enemies. He doubted the sincerity of the Liao message because he thought his virtue was not great enough to attract the Khitan, nor his majesty strong enough to awe them. Nevertheless, in his reply, Zhenzong expressed his willingness to negotiate peace, since it was his duty to bring peace and security to his people (SHYJG, 8: 7688).

With the conclusion of the treaty in 1005, formalised channels that shuttled Song and Liao envoys between the two capitals were established, and this enabled Song diplomats to make direct, personal observations of the Khitan. In order to acquire first-hand information about their northern neighbour, the Song court required their emissaries to keep detailed written records of their journeys and experiences (Hargett 1985 , p. 78$).{ }^{24}$ In addition to keeping record on travelling routes, natural geography,

${ }^{22}$ See Franke (1976, pp. 5-7) for a biography of Zhang.

${ }^{23}$ The translation is adopted from Wang (1983, p. 53).

${ }^{24}$ For a study of the Song ambassador system, see Franke (1983). On the chronology of diplomatic envoys between the Song and the Liao, see Nie (1935; 1940); Fu (1949); Zhang (1958). Selected reports of Song envoys to the Liao, collated and punctuated, are collected in Zhao (2017). For a French translation of five reports of envoys to the Liao, together with those of envoys to the Jin, see Chavannes (1897/1898). 
Liao government system, and diplomatic protocols, some envoys also learned the Khitan language and were therefore able to communicate directly with their Liao counterparts. Yu Jing 余靖 (1000-1064) and Diao Yue 习約 (fl. 1050s), for instance, even composed poems in Khitan, which were "favoured by the Khitan" (Qidan guo$z h i, 24: 8 b-9 a) .{ }^{25}$ Although only very few of these records are extant, there should be little doubt that they were invaluable to the Song and had considerably influenced the Song's image of the Khitan.

With the increase in knowledge about the Khitan, the Song recognised that the Khitan were stronger and more advanced than all other non-Chinese peoples China had ever encountered. Han Qi 韓琦 (1008-1075), chief chancellor in the 1050s and 1060s, noted that the Khitan had embraced Chinese culture and they had been competing with Chinese dynasties for hegemony for over a century since the Five Dynasties. Confident in their power, the Khitan considered themselves superior to all nonChinese peoples of the past and had even come to believe that they were superior to the Song (XZZTJCB, 150: 16b-17a; Tao-Wang 1974, pp. 438-439).

Similar points were expressed in another memorial by Han's colleague $\mathrm{Fu} \mathrm{Bi}$ 富弼 (1004-1083) who negotiated with the Liao for the second Song-Liao treaty in 1042. The Khitan, as Fu explained, had not only adopted Chinese institutions including government organisations, legal regulations, language and literature, but also possessed a formidable military machine that the Song lacked. Based on these facts, the Khitan should not be treated in the same way as the "barbarians" of ancient times. In urging for the Song to adopt a proper attitude toward the Khitan, Fu implied that the Liao should be regarded as a proper state and the Song, though the most civilised one, should realise that it was only one state among several other states (XZZTJCB, 150: $16 b-17 a)$.

Both Han Qi and Fu Bi played important roles in Song-Liao negotiations during the early 1040s. When tensions began to flare again due to the formation of a Liao-Xi Xia alliance, the Song sensed a potential double-sided threat from its northern and western borders (Ebrey 2014, pp. 375-376). Seeking ways to counter this threat, Emperor Shenzong called for open discussions of foreign affairs. Han and Fu, entrusted ministers of the emperor, were the chief proponents of the final decision to maintain peace with the Khitan, even at the expense of increasing annual payments (Tao 1985, pp. 63-70). Their realistic assessment of Liao power was fundamental to their recommendation for a rational course of action toward the Liao, which contributed to the successful solution to the new threat. At the same time, it was obvious that their assessment and attitude were influenced by the actual situation the Song was facing at that time.

The desire for peace did not mean that the Song court was unconcerned about its boundaries and national defence. From 1074 to 1076, the Song and the Liao held protracted negotiations to solve disputes over small swathes of borderlands. Before leaving for Liao as a special ambassador for the negotiation in the summer of 1075,

${ }^{25} \mathrm{Yu}$ Jing was thrice-commissioned as an envoy to the Liao in 1043, 1044, and 1045. Diao Yue was sent to the Liao in 1056. For a detailed examination of their poems, see Zhao (2017, pp. $36-37,58)$. 
Shen Kuo 沈括 (1031-1095), the premier statesman and scientist of his time, conducted thorough research at the State Letters Bureau to gather documents and maps to support the Song's claim. During six rounds of talks with Liao representatives, Shen firmly insisted that Song's maps of the areas in dispute were correct and refuted Liao's claims point by point (Zhang 1975; Tao 1985, p. 101). As a result, the Song was able to keep the Liao demands to a minimum and the border was re-established in Song's favour.

In fact, even before the 1040s, the scholar and Confucian historian Ouyang Xiu 歐陽脩 (1007-1072) had already warned the throne that the Khitan were unpredictable in nature and the peace treaty could not be considered permanent. ${ }^{26}$ Particularly worrying was the fact that as the Song-Liao frontier lines were more artificial than natural, they did not follow geographical demarcations that were easily defensible (XZZTJCB, 119: 6b). The construction of canals, fortification posts, and even plantation of willow trees would help to slow down the advances of Khitan cavalrymen, even though the Treaty of Chanyuan had proscribed such actions (XZZTJCB, 141: $9 a-11 a)$. Ouyang's view was supported by a number of officials who called for further strengthening national defence and preparing for an inevitable military confrontation (Tao 1985, pp. 125-126).

\section{Constructing a New Rhetoric of Cultural Superiority}

While Ouyang Xiu was clearly realistic in his assessment of the long-term prospects of Song-Liao relations, his personal attitude was not marked by cultural pessimism. The title of the section on the Khitan and other non-Chinese peoples in the New History of the Five Dynasties (Xin Wudai shi 新五代史), written by Ouyang Xiu during his exile from 1036 to 1039 and published in 1073, was a self-revealing one. Consisting of three chapters (juan 卷), a section was named "Appendix on Four Barbarians" (siyi fulu 四夷附錄). Although he acknowledged that the Khitan was the strongest amongst the "four barbarians", it was still one of them and an enemy of the "Middle Kingdom" (Zhongguo) (Xin Wudaishi, 72: 885; Liu 2004, p. 192). In doing so, Ouyang reaffirmed the demarcation between Chinese and non-Chinese within the Chinese world order.

In a few contemporary works, the use of derogatory terms for the Khitan was more frequent and direct. In some cases, the ancient names for barbarians, such as Xunyun 獯狁 and Xiongnu 匈奴, were used to refer to the Khitan. In a comment made by Song Taizong in 991, he noted that "the Xunyun today [i.e. the Khitan] are different from ancient barbarians in their numerical strength, their constant change in policy, and their deceitful tricks" (XZZTJCB, 32: 4b-5a). More often, "caitiff" (lu) was used to denote the Khitan. For example, in the Old History of the Five Dynasties (Jiu Wudai shi 舊五代史), published in 974, the rulers of the Khitan were referred to as "chief of the caitiffs" (luzhu 虜主), and the people as both "Khitan" (Qidan) and

\footnotetext{
${ }^{26}$ For a biography of Ouyang, see Franke (1976, pp. 808-816).
} 
“caitiff” (Tao 1985, p. 105). Wang Qinruo 王欽若 (960-1025), who was personally involved with the Song's decision to seek peace in 1005, complied the Prime Tortoise of the Record Bureau (Cefu yuangui 冊府元龜) both during and after the treaty negotiations. Wang used a series of terms ranging from neutral expressions such as the "Liao" and the "Khitan" to derogatory ones such as "caitiff", "northern caitiff" (beilu 北虜), and “barbarian caitiff” (ronglu 戎虜) (Cefu yuangui, 956: 11237-11241, 978: $11488-11497){ }^{27}$ Such mixed and contradictory use of terms is also seen in Ye Mengde's 葉夢德 (1077-1148) Talks of Swallows in the Stone Forest (Shilin yanyu 石林燕語):

"Now the Khitan have established a brotherly peace [with us]. [...] when [Yelü] Longxu (Emperor Shengzong) was on the throne, he was the elder uncle to [Song] Emperor Renzong (r. 1022-1164). During the regency of Empress Dowager Mingsu 明肅 (968-1033, mother of Renzong), the caitiffs sent embassies with letters to congratulate her on the New Year's Day and her birthday. Our dynasty also sent embassies to reply [to the empress dowager of the Liao]. As exchange of letters between the wife of the son's elder brother and the mother of the nephew, there is no enmity." (Shilin yanyu, 2: 3b $)^{28}$

Although he clearly acknowledged the fraternal relationship between the Song and Liao emperors, Ye did not feel that his wording would offend the imperial family by calling its Khitan relatives "caitiffs". These texts carrying terms insulting to the Khitan were circulating within the Song alongside those employing more neutral terms, which meant that they could eventually come to the Khitan's attention. It was probably due to such fear that the Song government issued strict bans, though not necessarily successful ones, on taking Song books into Liao territory, in particular volumes containing official documents or pertaining to current state affairs. ${ }^{29}$

While the usage of terms like "barbarian" and "caitiff" was meant to emphasise the demarcation between the "civilised" and the "barbarian" by resurrecting ancient terminologies, some Song scholars and officials were trying to develop a new set of rhetoric to culturally legitimise Song policy toward the Khitan. Ouyang Xiu was aware that the Song could not hope to best the Khitan in terms of military strength, let alone subdue them through assimilation or acculturation. To compensate for this political weakness in reality, Ouyang proposed a cultural approach to guide the Song's policy toward the Khitan. Reviewing historical events, he lamented that many past Chinese rulers had failed to formulate an effective way to deal with the northern and northwestern "barbarians", and whether or not the "barbarians" would invade

${ }^{27}$ See Franke (1976, pp. 1105-1109) for a biography of Wang.

${ }^{28}$ As formulated in the Treaty of Chanyuan, Song Shenzong, Renzong's father, was considered as the elder brother of Liao Shengzong. Thus when Renzong ascended the throne in 1022, the Empress Dowager of the Liao, Shengzong's mother, was considered the mother of Renzong's father's younger brother.

${ }^{29}$ On the Song prohibition on trading and smuggling books to the Liao, see Chan (1983, pp. 13-14); Liu (2002); De Weerdt (2006). 
China was an issue over which the Chinese could not exercise full control. Even the Spring and Autumn Annals (Chunqiu 春秋) mentioned cases in which Chinese sovereign had to make concessions to the "barbarians" in order to maintain peace (Xin Tangshu, 217a: 6151). As regards the reason for whether or not the "barbarians" would invade and whether concessions were necessary, the Confucian notion of the "Way" (dao 道) was the deciding factor. Ouyang pointed out that even when China possessed the Way, the barbarians would not necessarily submit; yet, when China lost the Way, the barbarians would not necessarily invade. Thus, he urged the rulers to exercise great caution in foreign policy, since mishandling the "barbarians" would bring disaster (Xin Wudaishi, 72: 885). Ouyang Xiu's mention of the Spring and Autumn Annals is meaningful here. Traditionally attributed to Confucius (551 BC-479 BC), this work is regarded as one of the Five Classics (Wujing 五經) of Confucianism. ${ }^{30}$ By citing this classic, Ouyang was attempting to rationalise the reality of Song-Liao diplomatic parity - after all, this was an issue that even the ancient sages were not able to solve effectively.

After diplomatic relations between the Song and the Liao was normalised in 974, Wang Yucheng 王禹偁 (954-1001) presented the "Hymn on the Northern Enemy's Submission" (Beidi laichao song 北敵來朝頌) to the throne to laud Song Taizu's accomplishment of attracting the "barbarians", i.e. the Khitans, to submit to China. Wang offered a brief description of the Khitan's savage customs and the traditional Chinese policies toward them, then he argued that the Song had employed the best policy, even superior to that of the Han and Tang dynasties'. This was because the Song relied on benevolence (ren 仁) in dealing with the non-Chinese peoples who lacked an advanced culture. The emperor, intending to "win the allegiance of the barbarians through kindness" (huairou 懷柔), treated them with propriety ( $l i$ 禮) and taught them with virtue ( $d e$ 德). By adopting such policies, the emperor not only rallied the people of the Song to support his rule, but also attracted the barbarians envious of China's culture. In Wang's eyes, the establishment of diplomatic relations meant that the Khitan, termed as the "northern barbarian" and referred to as the Xiongnu, came to submit to the Song in the same fashion as the earlier barbarian did to the ancient sage kings (Xiaochu waiji, 10: 475).

The rhetoric of elevating virtue and morality to compensate for martial weakness, shrouded in orthodox Confucian references, became increasingly common as the bilateral relationship progressed. Zhao Pu pointed out in his memorial to Song Taizong that wise rulers in the ancient times had not interfered in barbarian affairs and had placed them outside the Chinese civilisation. Their policy combined military prowess (wei 威) with virtue (de) (Tao 1985, p. 111). In his argument for pursuing diplomacy, Zhang Ji cited the successful examples of Han and Tang dynasties and noted that peace was necessary to turn danger into safety. However, he insisted that this was not because of a lack of strength:

${ }^{30}$ On the Spring and Autumn Annals, see Cheng (1994). An accessible translation of the work is Legge (1872). 
"Who would wish to exhaust resources of the Middle Kingdom to serve the worthless barbarian and harm our benevolence (ren 仁) and righteousness ( $y i$ 義) to quarrel with serpents and swine? Barbarian attacks in ancient times were merely compared with the sting of gadflies and mosquitos. [...] Now is the moment for binding friendship and resting the people. If Heaven above indeed regrets calamity and [cause] the rogues to appreciate our benevolence, it thus would accept our wish for friendly alliance and extinguishing the frontier beacons. This would be a great fortune to our ancestral altars." (SHYJG, 8: 7682) $)^{31}$

When the Treaty of Chanyuan was signed, it was clear that it was the Song who bought off the Khitan with an annual indemnity of silver and silks. Yet many Song scholars asserted that it was the Khitan who wanted to end the war because they admired the virtues and moralities of China. Zhang Fangping 張方平 (1007-1091), in his "Hymn to the Song" (Song song 宋頌), described the treaty as nothing but a glorious victory of the Song since it were the "barbarians" who submitted themselves to the great culture of the Song (Lequan xiansheng wenji, 5: $4 \mathrm{~b}-5 \mathrm{a}$ ). ${ }^{32}$ The renowned Neo-Confucians Cheng Hao 程影 (1032-1085) and Cheng Yi 程頣 (1033-1107) considered that the most important feature of the civilised Chinese is the practice of benevolence and righteousness. If they were even partially lost, the Chinese would descend into barbarianism; and if they were wholly lost, then people would sink to the level of animals. Therefore, all the ancient sage kings focused on benevolence and righteousness (Er-Cheng quanshu, 2a: 22b). For the Cheng brothers, during the period of disunity between 220 and 589 , both propriety and institutions were lost, therefore the barbarians had prevailed. Although the Han and Tang were considered powerful, their rulers ruled by force rather than benevolence, thus they were "not worthy of being followed" (Song mingchen zouyi, 129: 8a-15b). The emphasis on benevolence and righteousness reiterates itself in another poem by Shao Yong, a pioneer of Neo-Confucianism alongside the Cheng brothers:

The Armies of the Central Plain,

Based themselves on benevolence and righteousness.

When benevolence and righteousness are lost,

The four barbarians come to insult. ${ }^{33}$

Even Emperor Zhenzong was satisfied with the result of the treaty. Although a considerable amount of annual payments was to be conceded to the Liao, Zhenzong, like many of his ministers, perceived the treaty as an ideal example of a successful policy that combined power and virtue. After the conclusion of the treaty, he said to the court:

${ }^{31}$ For an unabbreviated translation of the text, see Wang (1983, p. 54).

${ }^{32}$ For a biography of Zhang Fangping, see Franke (1976, pp. 16-19).

${ }^{33}$ Translated from the poem “Moaning on the Central Plain" (Zhongyuan yin 中原吟) collected in Shao's anthology Yichuan jirang ji, 18: 137. 
"The northern borders have presented a threat [to us] since ancient times. [We] used to think about how to pacify them and all discussed about vanquishing the barbarians. Yet this would mean wars every day and high costs each year. Now [we] succeeded in making them fearing [our] military prowess and thus submitted to [our] righteousness. This has greatly comforted me." (XZZTJCB, 58: 18a-18b)

A corollary of such assertions was the belief that the Chinese culture was much more advanced than that of the barbarians and these culturally inferior people could be transformed by Chinese virtues. If the ruler successfully cultivated his virtue, which the barbarians cherished whole-heartedly, they would no longer desire to launch incursions and then voluntarily come to submit (Wang 1968, p. 43). Since the barbarian menace was not as serious as internal problems, the Chinese rulers' primary concern should be the pacification of their subjects and the cultivation of their virtue. Han Qi, for instance, held that all external threats started with internal problems. The barbarians were always alert so whenever there were internal problems occurring in China, they would invade immediately (Song mingchen zouyi, 131: 5a). Although Sima Guang and Wang Anshi 王安石 (1021-1086) were bitter political rivals on the issue of domestic reform, during the Song-Liao border dispute negotiations of 10741076, they both advised the throne that the emperor should first strengthen the Middle Kingdom and then conquer the barbarians (XZZTJCB, 237: 5a). ${ }^{34}$

\section{Concluding Remarks}

Despite initial military confrontations, the one event that set the tone for Song-Liao relations for over a century was the conclusion of the Treaty of Chanyuan in 1005, which was a de facto covenant agreed by both sides to replace hostile confrontations with a relationship of friendly tolerance. While it is true that the Song still employed a number of traditional policies to deal with the Khitan, this new model nevertheless marked the emergence of new dimensions in China's foreign relations. The Song never succeeded in achieving suzerainty over the Liao; on the contrary, it was obliged to pay annual tributes to its nomadic neighbour in order to forestall war. Yet, at the same time, despite extreme distinctions between the ruling houses of the two states, the Song had managed to establish a fictional "brotherly" kinship ties to the Khitan.

Of course, this newfound relationship did not mean that the Chinese emperors intended to debase themselves as equals or even vessels of "barbarians". Until the disastrous defeat in 979, Song rulers and officials were relatively confident of their military prowess; they readily made threats about military action and carried them out when necessary. It was only after 979 that the Song court realised, slowly and reluctantly, that its military strength was no match for the Khitan. This painful recognition was accompanied by growing readiness to tone down its grandiose rhetoric through

${ }^{34}$ For a detailed discussion of Wang Anshi's suggestions for policies toward the Liao, together with a discussion of those of Sima Guang, see Tao (1979). 
adoption of neutral terms in place of the more chauvinistic ones. After 1005, the Song had fully accepted bilateral diplomatic parity and conducted their policies to the Liao based on realistic assessments and diplomatic flexibility. At the same time, these policies were conducted with an air of unwilling forbearance; the Song rulers had to swallow their pride of supremacy in order to accommodate the existence of the powerful Liao in the Chinese realm (Liu 2004, p. 192).

To compensate for their military inferiority and confer political legitimacy on the status quo, the Song endeavoured to construct a narrative of cultural superiority over their nomadic neighbours. Although neutral terms were used to refer to the Khitan in diplomatic documents and government texts, derogatory terms such as "barbarians" and "caitiffs" still often appeared in memorials and private writings, in particular if those were not supposed to be acquired or read by the Khitan (Tao 1985, p. 105; De Weerdt 2006, pp. 477-478). With the increased contacts with the Khitan, the Song scholars and officials, even emperors, began to see that there could be a way to deal with the reality and the rhetoric separately. Instead of acknowledging their inability to conquer the "barbarians" in the north, they returned to traditional ideology and terminology to justify their concession to the Khitan by exalting Confucianism's core concepts such as virtue (de), benevolence (ren), righteousness ( $y i)$, and propriety $(l i)$.

It is therefore interesting to observe that the rise of the non-Chinese power of the Khitan in the north coincided with the rise of Neo-Confucianism in the Song. Almost all of the important figures of Neo-Confucianism in the Northern Song, as was shown above, had expressed their concern about Khitan incursions and commented on the proper course of foreign policy. One may presume that "the ponderance over non-Chinese powers in the north" caused the Chinese to search for their cultural roots in Confucianism (Wang 1999, p. 301). Of course, one may also argue conversely that it was Neo-Confucianism that reinforced the Song claim to be the cultural centre of "all under heaven". Whatever the case, the Song developed a new set of rhetoric to compensate for the dynasty's military weakness with confidence in is culture, thus continuing its practice of culturalism.

The dichotomy between the Song attitudes based on political reality and cultural superiority is not a clear-cut one, and it is best understood as a discrepancy between Chinese culturalism and ethnocentrism. Because of the renewed menace of "barbarian" prowess, the Chinese were forced to move away from their time-honoured ethnocentric perspective on the proper world order. However, they still clung to their avowed cultural superiority, hoping that the cultivation of virtue would make the "barbarians" voluntarily submit. In doing so, they succeeded in depicting "all under heaven" in a dualist fashion, one in which culture was separated from politics.

Nevertheless, the Song rulers and officials never completely relinquished their ambition of re-establishing an ideal world order that would affirm both China's political prowess and her cultural superiority. When the Khitan came under fierce attacks from the Jurchen in the 1120s, Emperor Huizong (r. 1100-1126) was determined to retake the "sixteen prefectures". To this end, he was willing to break the treaty with the Liao and seek aid from another "barbarian" people, the Jurchen. However, this policy backfired: the Jurchen ousted the Song from north China and seized even more 
territory from the Song, including its prosperous capital of Kaifeng (Kuhn 2009, pp. 66-69; Ebrey 2014, pp. 379-389, 399-419). After decades of painful efforts to consolidate the remaining territories in the south, the Song reached a hard-won treaty with the Jurchen in 1141, but its terms were more humiliating than any of the previous ones. A century later, the Song saw another opportunity when the Mongols attacked the Jurchen, and they again broke the alliance in the hope that the lost territories could be reacquired (Kuhn 2009, pp. 91-92). When history repeated itself, the Song had nothing left to concede to the Mongols, but to accept its dynastic downfall.

\section{References}

\section{Primary Sources}

Cefu yuangui 冊府元龜 [Prime tortoise of the record bureau]. Wang Qinruo 王欽若 (960-1025). Edited and collated edition. Nanjing, Jiangsu guji chubanshe, 2006.

Chunqiu Gongyang zhuan 春秋公羊傳 [Gongyang commentary to the Spring and Autumn Annals]. Ascribed to Gongyang Gao 公羊高 (ca. 5th cent. BC). Punctuated edition with annotation and modern Chinese translation by Wang Weidi 王維堤 and Tang Shuwen 唐書文. Shanghai, Shanghai guji chubanshe, 2004.

Er-Cheng quanshu 二程全書 [Complete book of Cheng brothers]. Cheng Hao 程影 (10321085)-Cheng Yi 程頣 (1033-1107). Edited by Zhu Xi 朱喜 (1130-1200). Shanghai, Zhonghua shuju, 1920.

Fan taishi ji 范太史集 [Collection of the grand secretary Fan]. Fan Zuyu 范祖禹 (1041-1098). Facsimile reprint. Taipei, Taiwan shangwu yinshuguan, 1983.

Huayang ji 華陽集 [Collection of Huayang]. Wang Gui 王珪 (1019-1085). Facsimile reprint. Shanghai, Shangwu yinshuguan, 1935.

Lequan xiansheng wenji 樂全先生文集 [Anthology of Mister Lequan]. Zhang Fangping 張方平. ca. 1090. Facsimile reprint. Beijing, Beijing tushuguan chubanshe, 2003.

Liaoshi 遼史 [History of Liao]. Toto 脫脫 (1314-1350) et al. Punctuated and collated edition. Beijing, Zhonghua shuju, 1974.

Nanyang ji 南陽集 [Collection of Nanyang]. Han Wei 韓維 (1017-1098). Facsimile reprint. Shanghai, Shangwu yinshuguan, 1935.

Qidan guozhi 契丹國志 [History of the Qidan State]. Ye Longli 葉隆禮 (fl. 1240s). Punctuated and collated edition. Ji'nan, Qilu shushe, 2000.

Shilin yanyu 石林燕語 [Talks of swallows in the Stone Forest]. Ye Mengde 葉夢德 (1077-1148). Beijing, Zhonghua shuju, 1984.

Song da zhaoling ji 宋大詔令集 [Collection of edicts and orders of the Song]. Completed in ca. 1140. Edited and collated by Si Yizu 司義祖. Beijing, Zhonghua shuju, 1962.

Song huiyao jigao [SHYJG] 宋會要輯稿 [Draft of documents pertaining to matters of state in the Song dynasty]. Xu Song 徐松 (1781-1848). Facsimile reprint. Beijing, Zhonghua shuju, 1957.

Song mingchen zouyi 宋名臣奏議 [Memorials and discussions by renowned ministers of the Song dynasty]. Zhao Ruyu 趙汝愚 (1140-1196). Facsimile reprint. Taipei, Taiwan shangwu yinshuguan, 1983.

Songshi 宋史 [History of Song]. Toto 脫脫 (1314-1350) et al. Punctuated and collated edition. Beijing, Zhonghua shuju, 1977. 
Su Weigong wenji 蘇魏公文集 [Anthology of Su Song]. Su Song 蘇頌 (1020-1101). Facsimile reprint. Shanghai, Shangwu yinshuguan, 1936.

Xiaochu waiji 小畜外集 [Additional collection of Wang Yucheng)] Wang Yucheng 王禹偁. Facsimile reprint. Shanghai, Shangwu yinshuguan, 1936.

Xin Tangshu 新唐書 [New book of Tang]. Ouyang Xiu 歐陽脩 (1007-1072)-Song Qi 宋祁 (998-1061). Punctuated and collated edition. Beijing, Zhonghua shuju, 1975.

Xin Wudaishi 新五代史 [New history of the Five Dynasties]. Ouyang Xiu 歐陽脩 (1007-1072). Punctuated and collated edition. Beijing, Zhonghua shuju, 1974.

Xu Zizhi tongjian changbian $[X Z Z T J C B]$ 續資治通鑑長篇 [Collected data for A Continuation of the Comprehensive Mirror for Aid in Government]. Li Tao 李壽 (1015-1084). Punctuated and collated edition. Beijing, Zhonghua shuju, 2004.

Yichuan jirang ji 伊川擊壤集 [Collection of Shao Yong]. Shao Yong 邵雍 (1011-1077). Facsimile reprint. Shanghai, Shangwu yinshuguan, 1922.

\section{Secondary Sources}

Chan, H.-L. (1983): Control of Publishing in China: Past and Present. Canberra, Australian National University Press.

Chavannes, E. (1897/1898): Voyageurs chinois chez les Khitan et les Joutchen. Journal Asiatique, Ser. 9, Vol. 9, pp. 377-442; Vol. 10, pp. 361-439.

Cheng, A. (1994): Ch’un ch'iu 春秋, Kung yang 公羊, Ku liang 穀梁 and Tso chuan 左傳. In: Loewe, Michael (ed.): Early Chinese Texts: A Bibliographical Guide. Berkeley, CA, Institute of East Asian Studies, University of California, pp. 67-76.

De Weerdt, H. (2006): What Did Su Che See in the North? Publishing Regulations, State Security, and Political Culture in Song China. T'oung Pao, Second Series, Vol. 92, Nos 4/5, pp. $466-494$.

Di Cosmo, N. (2002): Ancient China and Its Enemies: The Rise of Nomadic Power in East Asian History. Cambridge, Cambridge University Press.

Eberhard, W. (1949): Das Toba-Reich Nord Chinas: Eine soziologische Untersuchung. Leiden, Brill.

Ebrey, P. B. (2014): Emperor Huizong. Cambridge, MA, Harvard University Press.

Fairbank, J. K. (1941): On the Ching Tributary System. Harvard Journal of Asiatic Studies Vol. 6, pp. $135-246$.

Fairbank, J. K. (1968): A Preliminary Framework. In: Fairbank, J. K. (ed.): The Chinese World Order: Traditional China's Foreign Relations. Cambridge, MA, Harvard University Press, pp. $1-19$.

Feng Shengguo 馮盛國 (2016): Liang-Zhou shiqi hua-yi guanxi yanjiu 兩周時期華夷關係研究 [A study of the relations between Chinese and barbarians in the Western and Eastern Zhou dynasties]. Beijing, Zhongguo shehui kexue chubanshe.

Franke, H. (ed.) (1976): Sung Biographies. 3 vols. Wiesbaden, Franz Steiner.

Franke, H. (1983): Sung Embassies: Some General Observations. In: Rossabi, M. (ed.): China among Equals: The Middle Kingdom and Its Neighbors, 10th-14th Centuries. Berkeley, CA, University of California Press, pp. 116-148.

Fu Lehuan 傅樂煥 (1949): Song-Liao pinshibiao kao 宋遼聘使表考 [A study of the table of envoys between the Song and the Liao]. Bulletin of the Institute of History and Philology, Academia Sinica Vol. 14, pp. 57-136. 
Hansen, V. (2000): The Open Empire: A History of China to 1600. New York, W.W. Norton \& Company.

Hargett, J. M. (1985): Some Preliminary Remarks on the Travel Records of the Song Dynasty (960-1279). Chinese Literature: Essays, Articles, Reviews Vol. 7, No. 2, pp. 67-93.

Hsu, I. C. Y. (1960): China's Entry into the Family of Nations: The Diplomatic Phase, 1858-1880. Cambridge, MA, Harvard University Press.

Jiang, Wuxiong 蔣武雄 (2009): Su Song yu Huarong Lu-Wei xinlu: yibu shichuan de Song-Liao waijiao dang'an huibian 蘇頌與《華戎魯衛信錄》: 一部失傳的宋遼外交檔案彙編 $[\mathrm{Su}$ Song and Huarong Lu-Wei xinlu: A lost compilation of Song-Liao diplomatic documents]. Dongwu lishi xuebao 東吳歷史學報 Vol. 21, pp. 145-168.

Kuhn, D. (2009): The Age of Confucian Rule: The Song Transformation of China. Cambridge, MA, Harvard University Press.

Legge, J. (1861): The Chinese Classics, vol. 2: The Works of Mencius. London, Trubner Press.

Legge, J. (1872): The Chinese Classics, vol. 5: The Ch'un Ts'ew with the Tso Chuen. London, Trubner Press.

Legge, J. (1885): Li Chi, Book of Rites: An Encyclopedia of Ancient Ceremonial Usages, Religious Creeds, and Social Institutions. Edited with an introduction and study guide by Ch'u Chai and Winberg Chai. New Hyde Park, University Books.

Lewis, M. E. (2009): China between Empires: The Northern and Southern Dynasties. Cambridge, MA, The Belknap Press of Harvard University Press.

Liu Pujiang 劉浦江 (2002): Wenhua de bianjie: Liang-Song yu Liao Jin zhijian de shujin ji shuji liutong. 文化的邊界: 兩宋與遼金之間的書禁與書籍流通 [Boundaries of culture: Book prohibition and book exchange between the Song, Liao, Jin]. Chügoku shigaku 中國史學 Vol. 12, pp. 1-16.

Liu Pujiang 劉浦江 (2004): Deyun zhizheng yu Liao-Jin wangchao de zhengtongxing wenti 德運 之爭與遼金王朝的正統性問題 [The disputes on virtue and the question of legitimacy in the Liao and Jin dynasties]. Zhongguo shehui kexue 中國社會科學 No. 2, pp. 189-203.

Lorge, P. (ed.) (2011): Five Dynasties and Ten Kingdoms. Hong Kong, Hong Kong University Press.

Mancall, Mark (1963): The Persistence of Tradition in Chinese Foreign Policy. The Annals of American Academy of Political and Social Science No. 349, pp. 14-26.

Mancall, Mark (1968): The Ch'ing Tribute System: An Interpretive Essay. In: Fairbank, J. K. (ed.): The Chinese World Order: Traditional China's Foreign Relations. Cambridge, MA, Harvard University Press, pp. 63-89.

Marsone, P. (2011): La Steppe et l'Empire : La formation de la dynastie Khitan (Liao), IV $-X^{e}$ siècles. Paris, Belles Lettres.

Mote, F. W. (1999): Imperial China: 900-1800. Cambridge, MA, Harvard University Press.

Nie Chongqi 聶崇岐 (1935): Songren shi Liao yulu xingcheng kao 宋人使遼語錄行程考 [A study of the journeys and records of Song diplomats to the Liao]. Guoxue jikan 國學集刊 Vol. 5, No. 4, pp, 165-194.

Nie Chongqi 聶崇岐 (1940): Song-Liao jiaopin kao 宋遼交聘考 [A study of diplomatic missions between the Song and the Liao]. Yanjing xuebao 燕京學報 Vol. 27, pp. 1-51.

Rossabi, M. (ed.) (1983): China among Equals: The Middle Kingdom and Its Neighbors, 10th14th Centuries. Berkeley, CA, University of California Press.

Schwarz-Schilling, C. (1959): Der Friede von Shanyuan (1005): Ein Beitrag zur Geschichte der chinesischen Diplomatie. Wiesbaden, Harrassowitz.

Smith, R. (1996): Chinese Maps: Images of All Under Heaven. Oxford, Oxford University Press. 
Tao Jingsheng 陶晉生 (1979): Wang Anshi de dui Liao waijiao zhengce 王安石的對遼外交政策 [Wang Anshi's diplomatic policies toward the Liao]. Bulletin of the Institute of History and Philology, Academia Sinica Vol. 50, No. 4, pp. 657-677.

Tao Jingsheng 陶晉生 (1985): Song-Liao guanxishi yanjiu 宋遼關係史研究 [A study of the history of Song-Liao relations]. Taipei, Jinglian chuban.

Tao, J-S. (1988): Two Sons of Heaven: Studies in Sung-Liao Relations. Tucson, University of Arizona Press.

Tao Jingsheng 陶晉生-Wang Minxin 王民信 (eds) (1974): Li Tao Xu zizhi tongjian changbian Song-Liao guanxi shiliao jilu 李壽續資治通鑑長編宋遼關係史料輯錄 [Selected records of historical sources on Song-Liao relations in Li Tao's Collected Data for a Continuation of the Comprehensive Mirror for Aid in Government]. 3 Vols. Taipei, Institute of History and Philology, Academia Sinica.

Twitchett, D. - Tietze, K-P. (1994): The Liao. In: Franke, H. - Twitchett, D. (eds): The Cambridge History of China, Vol. 6: Alien Regimes and Border States, 907-1368. Cambridge, Cambridge University Press, pp. 43-153.

Wang, Cengyu 王曾瑜 (2005): Liao Song XiXia Jin de bihui, chengwei he paihang 遼宋西夏金 的避諱、稱謂和排行 [Taboo, appellation and seniority in Liao, Song, Xi Xia, and Jin]. Anhui shifan daxue xuebao (renwen shehui kexue ban) 安徽師範大學學報 (人文社會科學 版) No. 5, pp. 559-566.

Wang, G. (1963): The Structure of Power in North China during the Five Dynasties. Kuala Lumpur, University of Malaya Press.

Wang, G. (1968): Early Ming Relations with Southeast Asia: A background Essay. In: Fairbank, J. K. (ed.): The Chinese World Order: Traditional China's Foreign Relations. Cambridge, MA, Harvard University Press, pp. 34-62.

Wang, G. (1983): The Rhetoric of a Lesser Empire: Early Sung Relations with Its Neighbors. In: Rossabi, M. (ed.): China among Equals: The Middle Kingdom and Its Neighbors, 10th14th Centuries. Berkeley, CA, University of California Press, pp. 47-65.

Wang, Q. E. (1999): History, Space, and Ethnicity: The Chinese Worldview. Journal of World History Vol. 10, No. 2, pp. 285-305.

Wittfogel, K. A.-Feng, C.-S. (1949): History of Chinese Society: Liao (907-1125). Philadelphia, American Philosophical Society.

Wright, D.C. (2005): From War to Diplomatic Parity in Eleventh-Century China: Sung's Foreign Relations with Kitan Liao. Leiden, Brill.

Zhang Liangcai 張亮采 (1958): Bu Liaoshi jiaopinbiao 補遼史交聘表 [A supplement to the table of diplomatic missions in Liaoshi]. Beijing, Zhonghua shuju.

Zhang Yaqin 張雅琴 (1975): Shen Kuo yu Song-Liao huajie jiaoshe 沈括與宋遼畫界交涉 [Shen Kuo and the border negotiations between the Song and the Liao]. Shiyi 史繹 No. 12, pp. $10-25$.

Zhao Yongchun 趙永春 (2017): Fengshi Liao-Jin xingcheng lu 奉使遼金行程錄 [Records of journeys on mission to the Liao and the Jin]. Beijing, Shangwu yinshuguan. 